\title{
Ambiguities and Paradoxes of the Decent Work Deficit: Bonded Migrants in Tamil Nadu
}

\author{
Isabelle Guérin, University Paris I Sorbonne/Institute of Research for Development \\ Subramanian Ponnarasu, French Institute of Pondicherry \\ Govindan Venkatasubramanian, French Institute of Pondicherry \\ Sébastien Michiels, Bordeaux IV University/French Institute of Pondicherry
}

\begin{abstract}
This paper examines the brick kiln industry in Tamil Nadu as a case study to highlight the discrepancy between normative categories of decent work and workers' experiences and subjectivities. It highlights the extreme vulnerability of circular migrants while stressing the diversity of circulation channels and how these are both shaped by and constitutive of distinct eco-type systems and village economies. The paper also shows how employers and labour recruiters exploit many different forms of agricultural decline, and how they influence and take advantage of workers' constraints, expectations and aspirations. It is argued that debt bondage in the brick industry is supported by the decline in agricultural labour and lack of social protection but also partly by the growing consumption needs of labourers. Paradoxically, increasing aspirations for equality and integration are helping to reproduce the conditions for capitalist exploitation and extraction of surplus value.
\end{abstract}

\section{KEYWORDS}

brick kiln, capitalism, debt bondage, eco-type systems, labour standards, modernity

\section{Introduction}

This paper takes the case study of Tamil Nadu's brick kiln industry to highlight the discrepancy between normative categories of decent work and that of workers' subjectivities, showing how employers use and take advantage of the diversity of workers' lived experience. Industrial brick production is a typical form of neo-bondage (Breman 1996, 2007). Labourers become indebted to their employer via an advance that is contracted in the off-season in their place of origin. Combining wage advances, a piece rate system and postponed payment allows employers to attract a loyal, underpaid labour force while ensuring productivity. Debt bondage is the polar opposite of decent 
work, forcing labourers to work for low or zero wages because they are struggling to repay a loan. Recent evidence suggests that debt bondage is a widespread form of forced labour, particularly in South Asia and above all in India (ILO 2009). While 'old' forms of agrestic bondage are fading away, new forms are emerging which often qualify as 'neo-bondage'. ${ }^{1}$ In contrast to older forms of bondage, which were embedded into a wide set of rights and obligations and were often intergenerational, neo-bondage is time-restricted and more economic in nature (Breman 1996). Neobondage is present in a wide variety of seasonal work sites such as brick kilns, saltpans, stone quarries, construction sites (irrigation canals, dams, road building). It can also be found in the agro-business industry (e.g. sugarcane harvesting) as well as in rural or urban-based industries (mines, rice mills, small-scale carpet and weaving workshops, gem processing ateliers, bidi making, fish processing, silver work, salt plains, etc.) (Breman et al. 2009, Lerche 2007, Srivastava 2009). Neo-bondage is estimated to incorporate around 10 percent of the working population in the informal sector in India's urban and rural economy, namely around 40 million (Breman 2011: 345, Heuzé 2009). It appears to originate from the combined effects of social hierarchies, chronic under-employment and specific modes of extraction of labour surplus (Breman 2007, Bremanet al. 2009, Lerche 2007, Srivastava 2009). On the labour side, the decline of agricultural employment in many parts of rural India has created masses of poor people and a reserve army of both vulnerable and incredibly malleable labour. Agricultural labour has declined over the past few decades, whether through the adoption of capitalist technology and less labour-intensive production, or the severe crisis faced by small peasants (Ramachandran and Rawal 2011). The total share of agricultural work in rural labour was 77.7 percent in 1983, in contrast to 66.5 percent in 2004-2005 (Srivastava, this volume). For capital, bondage can be a deliberate strategy to discipline and control seasonal labour (Breman 2007, Breman et al. 2009). But it may also help to attract and retain skilled workers, as in the case of weaving (De Neve 2005), diamond (Engelshoven 1999) or gem-cutting industries (Kapadia 1999). It can also be a way to block so-called self-employed workers' free access to the market, as observed in coal mines (Heuzé 2009). Bondage as a labour management strategy evolves with technological change and/or market fluctuations. When markets stagnate or decline, the advance system may become less attractive (de Neve 2006) or even disappear (Engelshoven 1999). Conversely, when markets are booming, bonding labourers with debt can be a way to cope with the 'labour problem' (i.e. attracting and disciplining workers). This is especially true with brick kilns: given that there is continuous growth in a dynamic construction sector, migration and debt are increasingly strategically used by employers to attract and control labourers while maintaining very low wages.

Labourers' subjectivities, however, hardly fit with normative categories of labour standards and this is what the paper intends to explore. We are not the first to highlight the ambiguity of these contemporary forms of bondage. It is well-known, for instance, that where there are very high unemployment rates and sharp fluctuations in labour demand, workers may experience dependency on an employer or a recruiter as a safeguard and as job security. In the brick kilns, many workers do not experience advance payment as bondage, but as a strengthened bargaining position (Breman 2007: 88; see also Guérin and Venkatasubramanian 2009). In a climate of violence and in the absence of formal institutions guaranteeing everyone's basic rights, dependency on an employer or recruiter might appear as a form of 'protection', as thin as it might be in practice (Heuzé 2009, Picherit 2009). Moreover, regardless of its conditions, migration might be considered a form of 
emancipation where local social norms are oppressive. In a provocative essay on brick kiln migrants in Jharkhand, Shah (2006) for instance argues that far beyond economic motivations, and notwithstanding harsh working conditions, brick kiln migration is frequently experienced as a liberation from local oppression resulting from rising moral Puritanism in areas such as sexual lifestyles, food or domestic disputes.

In the same vein, this article aims to highlight workers' subjectivity and agency, considering their diversity and how they are constitutive of workers' exploitation. Although all brick kiln migrants are bonded, poor and from the most marginalized community in Tamil Nadu (Paraiyar, exuntouchables), we argue that brick labour incorporates a wide range of strategies, perceptions and experiences. Labourers indicate in their narratives that they experience bonded migrancy either as a means to integrate and participate in the global economy, or as a sign that they are no longer in a position to work on the land. We argue that migration patterns and workers' subjectivities are shaped by and constitutive of local production relations, within which agro-ecological conditions play a central role, in particular as regards the distinction between dry and irrigated zones. As various works on both past and present rural South India have pointed out, eco-type distinction pertains not only to matters of agricultural production but also to social stratification, shaping identities, the intensity of dependency ties and the extent to which caste and class overlap.

Stressing migrants' subjective feelings of upward mobility does not mean we should underestimate the violence of bonded labour. On the contrary, workers subject themselves to extremely bad working conditions not only because they have no other choice, but because of this feeling of relative upward mobility. In order to understand the current logics of capital, we need to examine not only how capital exploits labour, but also how capital accommodates, facilitates or blocks labourers' aspirations for modernity. Our analysis shows how labour intermediaries and employers use a variety of strategies to discipline the workforce while taking advantage of distinct circulation channels, which in turn strengthens them.

In short, the most inexperienced and vulnerable wetland workers suffer from the worst working conditions and are considered a flexible workforce to be used at peak production times. By contrast, dry land labourers, who have specialized in brick moulding for almost four decades, have learnt the tricks and techniques of this particular migration channel. They are considered a permanent and 'reliable' workforce and have stronger bargaining power, which they use to obtain slightly better working conditions. However they also use their position to obtain high advances, which feed their growing needs for consumerism, which arise from their migrant worker status. These advances mainly reinforce their own exploitation. As a result, as paradoxical as it might be, employment standards violations are not only compatible with rising aspirations for equality and integration, as exemplified by the desire for consumption, but they rely on them.

\section{Setting}

Because of the strong growth in construction sector, Tamil Nadu is one of India's most important brick making states (Prakash 2009). Our study focused on brick kilns in the Tiruvallur and Kancheepuram districts (north-east of Tamil Nadu), where a significant portion of the production is concentrated. We studied 10 hamlets located around $150 \mathrm{~km}$ south-east of production 
sites in the Villupuram district (formerly South Arcot), where a significant part of the population migrate for brick kiln work every year.

Our fieldwork began in 2003. Three of us spent intensive time in the villages between 2004 and 2006 and then continued with regular visits until 2009, mainly in the villages but also at the workplaces. We focused on the lowest castes (Paraiyars, ex-untouchables) as they represent the bulk of the subaltern workforce in the brick industry. A large part of the research was qualitative and aimed at understanding both the functioning of the industry and the labourers' experiences. The fieldwork concentrated on the workers, but we also held many interviews with recruiters, who as we shall later discuss play a decisive role, and with supervisors and employers. We also spent time studying the functioning of village life, which was quickly apparent plays a central role in the fabric of migration patterns. In order to quantify specific information such as living and working conditions, we also carried out a household survey. In 2004 we interviewed 198 households, which were randomly selected from two sets of dry and irrigated villages.

Working conditions in the brick kilns are very poor. Wages are miserable (around 45 INR per day in 2004, that is around 1US\$), working days are extremely long (twelve to sixteen hours, half of which are at night), and workers experience ongoing exposure not only to dust and heat, but to harassment from brick kiln supervisors, unsanitary conditions, etc. (Guérin and Venkatubramanian 2009). Here our focus is labourer heterogeneity. To understand this we first used a Multiple Correspondence Analysis (MCA). MCA as a statistical technique allows the analysis of the relationship pattern of several categorical dependent variables. For a given sample of heterogeneous individuals MCA is usually used to build typologies, with the two main purposes of collating the most similar individuals, and then identifying the most important sources of similarities and dissimilarities. Given the multiplicity of interrelationships between variables, a regression-type analysis, aiming at quantifying causality, was not suitable.

Our MCA was designed to classify households according to their socio-economic characteristics and place of residence (Michiels 2009). In terms of the most important results, our analysis revealed two sets of differentiating factors: firstly place of origin (wet/irrigated), and secondly a number of socioeconomic and household demographic characteristics. Two distinct groups of workers emerged, the first consisting of households coming mostly from dry areas (92 percent). They are economically better off, more often owning a piece of land and concrete houses, more jewellery, and often not experiencing food insecurity. ${ }^{2}$ These households are bigger, older and less educated. Most are able to borrow outside the usual sources of pawnbrokers and landlords, and they more frequently combine brick kiln with agriculture on their own land for a living. The second group consists of households with the opposite characteristics. They mostly come from irrigated areas (98 percent) and are economically more vulnerable, with fewer assets, no land, poor housing and many suffering from food insecurity. Very few borrow from outside the usual sources, this perhaps indicating that their social network is restricted. These households are also younger, smaller and slightly better educated at both primary and secondary level.

Given that ecotype system distinctions emerged as a central factor, we then looked to focus on the reasons and meaning behind this distinction. Our analysis suggests that these two groups reflect distinct patterns of circular migration, which in turn are both shaped by and constitutive of 
distinct village economies and forms of integration into the global economy. The next section explores the fabric of these differing circular migration patterns.

\section{The Fabric of Circular Migration Patterns}

Labourers' agency is significantly affected by what they are likely to be offered in terms of employment, safety nets and protection by the villages of origin or workplaces. Given that the basic rights of labour exist on paper but are implemented mainly through personal bonds of allegiance and patronage, the poor seek out the most supportive - or least hostile - environments. As argued by Wood (2003), when the poor negotiate their own agency they have no choice but to arbitrate between the local moral economy, which is both protective and oppressive, and migration as a potentially liberating but extremely risky exit. This kind of dilemma certainly exists in Tamil Nadu, where agricultural employment has declined much more markedly than elsewhere in India, but at varying levels depending on the region and territory (NCEUS 2007). Local patronage has also eroded, but in a number of different ways. Village moral economy ethnographies indicate that patronage can decline, persist or take new forms, ${ }^{3}$ especially with the blossoming of public and private anti-poverty programs, for which local elites often act as intermediaries (Pattenden 2011; see also Picherit, this volume). Changes in agricultural labour and local patronage shape both the nature and intensity of circulation flows. In our case study, socioeconomic and political changes are closely associated with eco-type distinctions. These are not only a matter of production processes, technical constraints and crop type. Agro-climatic conditions are also constitutive of identities, social hierarchies and both spatial and social mobility circuits. Available literature indicates that drylands are more likely to have better landownership distribution, a greater dependence on outside and non farm labour - whether rural or urban - and lower caste interdependence. ${ }^{4}$ The low value of the land makes it more accessible, while job scarcity causes circulation. This in turn allows for the loosening of local ties of dependence and a broadening of horizons, expectations and aspirations, as pointed out for instance by Epstein (1973). To be free may simply mean freedom to starve (Breman 1996). What is certain however is that the physical character of the land is instrumental in the making and unmaking of local systems of rights and obligations. As we shall see here, it is also instrumental in forging varied degrees of rural/urban inter-linkages and in doing so in the shaping of labourers' agency, the range of their constraints as well as their expectations and aspirations.

While the district of Villupuram is one of Tamil Nadu's most important agricultural producers, circular migration to both rural and urban destinations is widespread. As elsewhere in the state, the nature and the intensity of rural-urban linkages are highly diverse. Land quality and water availability, crop type, particularly in terms of labour intensiveness, proximity to transport infrastructures, social networks and individual circumstances all contribute to this. The Pennaiyar River crosses the district from west to east, from which many irrigation canals are derived. Nearby villages can produce two to three crops per year and enjoy both water and a rich alluvial soil. Moving away from the delta, the land becomes rocky, and the water table dries up. Farmers limit their production to one or possibly two crops a year, focusing on crops demanding little water such as groundnuts, black gram (lentils) and ragi (a millet). With the passing of the years, the gap has widened between those owning land and who managed to dig a well, and the others. Water resources 
have significantly degraded: in the villages we studied, farmers say that they have to $\operatorname{dig} 250$ feet to reach water, as opposed to 100 feet twenty years earlier. As a result, migration and circulation have steadily increased. Not all wet villages are necessarily agricultural however. Roadside villages notably have contributed to building rural-urban interlinkages. More recently the introduction of low-labour intensive crops such as fruit has tightened local labour markets, forcing the workers and especially the landless to move out.

Circulation channels are both multiple and segmented. ${ }^{5}$ Villupuram district is no exception. Higher castes and classes are more likely to create businesses and to invest in profitable urban-based activities such as transport, construction or moneylending in nearby small and medium-sized towns such as Villupuram or Pondicherry. Those at the bottom of the hierarchy are more likely to enter into debt bondage relationships, most often as sugar cane harvest or brick kiln labourers. Meanwhile many activities hover between disguised wage work and self-employment, such as masonry work on construction sites and loading or unloading in markets. Circular migrants are mainly male, while debt bondage can involve whole families, as discussed later: women, the elderly and children are drafted in to raise productivity and to help pay back the advance. Migration channels are also shaped by individual circumstances where personal relationships are fundamental (Racine 1994). The emergence and evolution of migration channels to the brick kilns reflects these combined structural factors and individual circumstances.

\section{Brick Kiln Circular Migration From Dry Areas}

Large-scale brick kiln production on the outskirts of Chennai dates back to the mid 1970s. The massive expansion in production rapidly led to the use of migrant labour. Initially employers themselves went to the villages to recruit labourers. They focussed on dry villages which were already active in local traditional brick moulding. ${ }^{6}$ At the time there were only very small units of production in the countryside, which lasted only for the time of moulding and baking. Such production units, which are less common today, were often managed by the local middle castes (Vanniyars) while the workforce consisted of Paraiyars. Modern brick kilns managed to reproduce this labour hierarchy: Vanniyars were recruited as loaders and firemen, and then as labour intermediaries, while Paraiyars made up the bulk of the subordinate workforce as moulders. The advantages of employing the dry village labourers included that they were ready and available to leave their village for six to eight months per year, and desperate enough to accept very poor employment conditions. Employers were also looking for 'reliable' and 'hard' workers, which is where personal contacts came in. To control workers requires powerful networks in the source village. Villages whose workers were considered the most committed gradually gained a good reputation with employers, while others were discarded. Nowadays employers still discuss these matters and exchange information, drawing up black lists of places not to recruit from because workers from there are more rebellious than elsewhere, or because alliances with local leaders are more difficult.

To return to the evolution of brick kiln worker circulation, workers considered the most reliable, primarily selected from the Vanniyars, have taken charge of recruiting and controlling labour, and distributing advances. What began as a marginal phenomenon gradually led to massive flows of seasonal migrants who travelled back and forth every year, dividing their time between the 
brick kilns and their home place. Whole colonies of Paraiyars have gradually specialized in brick making. Nowadays brick kiln circulation sustains whole village economies. In the villages of our case study, around 90 percent of Paraiyar households work in the sector. Brick kiln circulation is both continuous and family-based. Most labourers bring other household members with them, with an average of three members. 80 percent have never stopped migrating, and it was once described to us as 'our gold and our god'. The villages are thus deserted for part of the year.

Initially the Paraiyars had little choice, as there was no local employment available. Over time they have managed to reap some benefits, and many of them today - 73 percent according to our survey - consider that their situation has improved over the past 25 years, although inequalities have increased as we shall see later. They insist on the hardness of the work, are perfectly aware of the extent of their exploitation. Mothers aspire to escape from the hell of the brick kilns when they discuss their daughters' weddings. Brick moulding is not seen as a something positive in itself, but rather as a source of progress as it allows the workers to escape from the oppressive realities in the home villages and enables changes to these realities (in line with Shah 2006). ${ }^{7}$ Labourers' subjectivities should be viewed in the light of broader evolutions in village life. The construction industry boom has coincided with significant changes in land ownership and management in these villages. From the 1970s onward most upper castes - Reddiars, Naidus, Chettiars, Mudaliars - had begun to desert the area, selling all or part of their land and relocating to urban areas. Most still own a house in the area, but no longer live there. The Paraiyars who used to work for them were therefore forced to seek a new source of livelihood. Land transactions mostly benefited the middle caste Vanniyars, who today are the main landowners. As Béteille observed of another Tamil district (Béteille 1965), these changes have tended to loosen the grip of caste on many areas of social life. Attached labour for instance has totally disappeared after persisting until the 1980s, when it slowly started to fade with the departure of upper castes. The sense of independence is particularly evident when social and religious rituals are held, where gaining prestige and status depend upon the scale of the ceremony, the degree of ostentation, but also upon its mode of financing. Paraiyars traditionally used to rely on their landlords, but now manage a loan by borrowing considerable sums from multiple sources. During one of our field visits, Mayavel, a Paraiyar maistry (labour intermediary), showed us around the small temple that he had managed to build with his brothers, and the first thing he told us was: 'we have built it without their money'. 
Table 1. Labourers from the drylands. Socioeconomic profile

\begin{tabular}{|l|l|}
\hline $\mathrm{N}=103$ & \\
\hline Concrete housing (\% HH) & $31.10 \%$ \\
\hline House size (\% HH with more than 2 rooms) & $14.60 \%$ \\
\hline Average size of the HH & 5.35 \\
\hline Illiteracy level (\%HH) & $57.70 \%$ \\
\hline Landowners (\%HH) & $52.42 \%$ \\
\hline Food insecurity (\% HH) & $19.42 \%$ \\
\hline Extended social networks (\%HH) & $67.90 \%$ \\
\hline $\begin{array}{l}\text { Average total household income per year in INR } \\
\text { dispersion) }\end{array}$ & $30016(15843)$ \\
\hline$\%$ Brick kiln income / total household income & $75.6 \%$ \\
\hline Occupation other than brick kiln work & $51.4 \%$ \\
\hline $\begin{array}{l}\text { Agricultural production } \\
\text { Agricultural coolie } \\
\text { Casual urban-based job } \\
\text { Permanent job } \\
\text { Total }\end{array}$ & \begin{tabular}{l}
$51.1 \%$ \\
$5.6 \%$ \\
\hline Average outstanding debt in INR (dispersion) \\
\hline Ratio outstanding debt / total income
\end{tabular} \\
\hline Average cost of marriages in INR & $100 \%$ \\
\hline
\end{tabular}

Source: fieldwork

Although the Paraiyars are still at the bottom of their local social hierarchy, many still consider their situation better than that of their parents, often stating: 'we have improved'. This highlights a general sense of an improved position within the local hierarchy, where they are no longer fully controlled by the upper castes and can even compete with the Vanniyars. Labourers are proud to say 'we work outside'. The kind of work they do is not a concern - for most, it is brick kiln work but it could just as easily be anything else, as what counts is to feel independent.

Such improvement proves highly unequal and ambiguous at the household level, however. Brick moulding has certainly prevented most, although not all workers, from starving. Today, 19 percent still suffer from food insecurity. The average annual income is $30016 \mathrm{INR}$, and most of them are still poor. ${ }^{8}$ However the ability to access cash, the desire to climb in the local hierarchy, and the success of a few is pushing most of the others to borrow large sums of money for consumer 
expenditure and ostentatious purchases. This debt burden inevitably restricts possibilities for significant improvements.

These hamlets' brick kiln workers define themselves and are seen by others as people 'who access money'. This means that they are both able to borrow money and to lend to others. Several interrelated factors contribute to this. Firstly, the wage advance of course is key. The advance represents a lump sum otherwise out of reach for Paraiyars. In 2004, the advance amount per household was on average 12,287 INR, which is 40 percent of the average annual household income. When the workers have good established relationships with their maistries and need bigger sums for instance for marrying their children - they can negotiate several years' worth of advance. Reciprocal exchanges with relatives are also frequent, where a household will take two years worth of advances and give up its turn the following year. With such arrangements, a single household can easily obtain 50,000 INR in one payment. Secondly, the very fact of being a brick kiln worker gives them to access to many other sources of funds, both in the village and the workplace. The advance serves as a form of guarantee, as payments to other lenders can be made from this and, in addition, maistries quite often act as official guarantors. Most households are thus highly indebted. The average outstanding debt per household was 25,101 INR, which represents 83.6 percent of the average annual income. The purposes for which the money is used also matter. According to our survey, 95 percent of the families spend part of the advance on daily survival (Table 2). But some manage to use it for a 'good cause', which can mean a variety of things. It can be firstly an investment in self-employment activities such as small businesses ( 7 percent of the households have used part of the advance for this purpose) or agriculture (34 percent). In both cases, profits are meagre and uncertain. In the case of agriculture, 50 percent of households are small producers. 71 percent earn an average of less than 5,000 Rs per year, and lose money in some years. Notwithstanding financial gains however, the very fact of being self-employed is highly valued. Running a petty business or cultivating one's own land was something their parents barely knew of. Although this was not reported in the questionnaire, advances are also frequently used to lend money to others, usually with interest. 
Table 2. Advance use (labourers from dry villages)

\begin{tabular}{|l|l|}
\hline & Dry areas \\
\hline Food & $94.3 \%$ \\
\hline Health & $21 \%$ \\
\hline Household items & $14.3 \%$ \\
\hline Education & $1.9 \%$ \\
\hline Marriage & $8.6 \%$ \\
\hline Other ceremonies & $12.4 \%$ \\
\hline Housing & $2.9 \%$ \\
\hline Business investment & $6.7 \%$ \\
\hline Agricultural investment & $34.3 \%$ \\
\hline
\end{tabular}

Total exceeds $100 \%$ because of multiple responses

Source: fieldwork

Social events and rituals are also considered a 'good cause'. 20 percent of the households had spent part of their advance for this purpose. In these hamlets the cost of social and religious events has significantly increased over recent decades, to which the wage advance is likely to have contributed. While their own marriage barely cost a few thousand rupees, labourers now spend tens of thousands for their children's: in 2004 the average amount spent was 32,000 INR. 28 percent of households had spent more than 50,000 INR. Detailed analysis of the funding of marriages highlights the fundamental role of wage advances. The events are experienced with ambivalence, as they are incontestably a source of dignity and social recognition, both for individuals, households and the whole community. Paraiyar brick kiln labourers are often proud to state that they use the same marriage halls as the Vanniyars. Many however complain about the burden of social pressure: we were often told spending big money had become a 'duty'. People say that they spend much more than they can afford, because they are able to 'access money'. There are frequent reports of brick kiln labourers trying to 'follow the urban culture', making their desires exceed their financial means.

Last but not least, patterns of improvement are highly unequal. Around 15 percent of brick kiln workers in these hamlets are better off than the rest. They own concrete houses with two rooms, and earn over 40,000 INR per year. Most of the households own at least two acres of land and combine their surplus from the land with brick income. The best off work as maistries, of whom there are very few (4 percent in our sample). Many have tried to become maistries but very few have succeeded. As with any marginalized group social mobility process, the maistries attract both envy and jealousy. Feelings are all the more ambivalent given that the maistries to some extent reproduce the ambiguity of the hierarchical relations with their own caste fellows, in a mixture of protection and exploitation (Breman 1996, Guérin and Venkatasubramanian 2009, Picherit 2009). In the 
villages studied here, the well-established maistries are all involved in politics, either through alliances or direct party representatives. Their role is also to help workers to take advantage of the few rights they have in the village. What is important for the purposes of the present analysis is the fact that they act as role models. For instance Mayavel, who managed to build a small temple, is often cited as an example. A few years earlier he was an ordinary labourer, who then managed to climb the social ladder. His story demonstrates to people that some sort of upward mobility is possible. Other workers often talk about him as a 'big man'. There is no doubt that these few success stories lead to desires and aspirations.

\section{Brick Kiln Circulation From Wet Areas}

In the mid-1990s, brick kiln work also began to become a source of employment in certain irrigated areas, and in particular in those areas which had opted for less labour intensive crops, i.e., where villages had partially converted from paddy and sugar cane to guava and flowers. Many agricultural workers, and particularly men, were thus forced to seek a living outside the village. Brick kilns are one option among others, while sugarcane harvesting work in the south of the state is another frequent destination. The proportion of migrants is much lower than in dry areas. We estimate that around 20 to 30 percent of Paraiyar households are involved. Compared with dry areas, brick kiln migration is a more recent phenomenon. A quarter of the workers (23.4 percent) from wet zones began more than 10 years ago, while over half did from dry zones (55.7 percent) For many (67 percent), it is a temporary option to which households resort when local agriculture labour is unavailable. It is also more often undertaken individually, and only 37.5 percent of the households bring their whole family, as opposed to 86.9 percent from dry areas. In many cases, brick production is not part of their livelihood portfolio; deciding for bricks depends upon specific circumstances: one's own needs or the brick kiln industry employment demand.

The wet hamlets in our case study are still typical of an agrarian economy, characterized by both the importance of agriculture and strong caste interdependence. In wet areas, the higher value of the land frequently makes it less accessible to the lowest castes. Here, Paraiyars have never owned land and nor do they today. This is particularly the case for those who migrate to the brick kilns. Most big landowners, all of whom are high caste, increasingly combine agricultural and nonagricultural income, but they still cultivate land and live in the village. Over the past few decades agriculture has become increasingly capital intensive, especially for big farmers. This started in the 1970 s with the introduction of sugar cane. A new shift came in the mid-1990s with the introduction of less labour-intensive crops such as fruits. The ensuing shortage of labour demand accelerated the attached labour system's disappearance, while circular migration became increasingly common. However the experience of circular migration, whether in terms of its social meaning or material conditions, differs sharply from the drylands. 
Table 3. Labourers from the wetlands. Socioeconomic profile

\begin{tabular}{|l|l|}
\hline $\mathrm{N}=98$ & \\
\hline Concrete housing (\% HH) & $4.20 \%$ \\
\hline House size (\% HH with more than 2 rooms) & $0.00 \%$ \\
\hline Average size of the HH & 4.47 \\
\hline Illiteracy levels & $44.2 \%$ \\
\hline \% of landowners & $6.30 \%$ \\
\hline Food insecurity (\% HH) & $96.84 \%$ \\
\hline $\begin{array}{l}\text { Extended social networks ((\% HH who can borrow } \\
\text { money outside usual sources) }\end{array}$ & $15 \%$ \\
\hline $\begin{array}{l}\text { Average annual total household income } \\
\text { (dispersion) }\end{array}$ & $16766(2720)$ \\
\hline \% brick kiln income / total household income & $85.6 \%$ \\
\hline $\begin{array}{l}\text { Agricultural production } \\
\text { Agricultural coolie } \\
\text { Casual urban-based job }\end{array}$ & $1.9 \%$ \\
Permanent job & $76.7 \%$ \\
\hline Average outstanding debt (dispersion) & $21.4 \%$ \\
\hline Ratio outstanding debt/ total income & $0.0 \%$ \\
\hline Average cost of marriages in INR & $6100 \%$ \\
\hline
\end{tabular}

Source: fieldwork

In wet villages, agriculture is still considered a main occupation and as a primary aspiration. Working outside the village is most often viewed as a last resort and a way to make ends meet between two harvests, and it is only the most vulnerable who go. As indicated in Table 3, almost all of them suffer from food insecurity (96.84 percent), very few have concrete housing (4.2 percent) or land (6.4 percent). Their average annual incomes are far below decent living conditions (16,766 INR), and most of it (85.6 percent) comes from brick labour. Most of the stories are similar: the workers leave to work in the brick kilns to pay off a debt due to marriage, death or illness. Here too contracting an advance before leaving for the chambers is a rule but amounts are lower than in dry lands (8,849 INR on average per household). In contrast to dry lands, the advance is almost exclusively used for emergency expenses. It is 'like a cloud', as the labourers often say. Investments, whether economic or non economic, are only exceptional (see Table 4). 
Table 4. Advance use (labourers from wetlands)

\begin{tabular}{|l|l|}
\hline & Irrigated areas \\
\hline Food & $91.3 \%$ \\
\hline Health & $18.3 \%$ \\
\hline Household items & $38.5 \%$ \\
\hline Education & 0 \\
\hline Marriage & $12.5 \%$ \\
\hline Other ceremonies & $1.9 \%$ \\
\hline Housing & $24 \%$ \\
\hline Business investment & 0 \\
\hline Agriculture investment & $2.9 \%$ \\
\hline
\end{tabular}

Total exceeds $100 \%$ because of multiple responses

Source: fieldwork

Labourers' responses as to why they do not migrate more often are very clear: they define themselves as 'peasants' and often state: 'we are born to the land and this is our land'. Even if most are landless, they are strongly attached to the village and agriculture. This might be a question of habit and identity or simply a lack of alternatives: some want to leave, but fail as they lack contacts with labour intermediaries.

Staying in the village is also a matter of security. Brick kiln advances far exceed the amounts that workers can get locally, but being away from the village for around six months cuts them off from numerous local protection links. Labourers say that they lose 'many sorts of help' from the upper castes, which include the potential access to labour, loans, governmental schemes or NGOs. Conversely, upper castes are categorical that they do not provide 'help' or 'recommendation' for those who are unavailable for work. Although the upper caste landowners are not the masters they used to be, primarily because they fail to provide jobs, they still behave as benevolent patrons. Social and religious rituals illustrate this. In comparison to dry lands, rituals in wet areas are much less conspicuous - on average households spend three times less - and moreover they are still funded in large part by upper castes.

\section{Production Sites: Diversity of Workers and Forms of Exploitation}

Heterogeneous circulation patterns are both reflective and constitutive of differences in positions within the industry, degrees of bargaining power and thus differing working conditions. Workers' capacity to resist exploitation is extremely limited. This is even more the case for migrants coming from wetlands. Incomes are lower: according to our survey in 2004, the average wage per head and per season was 5,863 INR for workers from the wetlands as opposed to 7,656 INR from 
the drylands, namely 23 percent lower. Their working conditions and relationships are worse (see Table 5): child labour is more prevalent, housing conditions are poorer, workers have fewer days off, freedom of movement is highly limited, wage conditions are not transparent, and the workers complain more frequently of harassment and cheating problems. They are less frequently able to bargain, and those who try do so mainly as regards the advance, while workers from the dry zones negotiate wages.

\section{Table 5. Working conditions}

\begin{tabular}{|l|l|l|}
\hline & Labourers from dry areas & Labourers from wetlands \\
\hline $\begin{array}{l}\text { \% of HH who use child labour } \\
\text { to move from the workplace (to } \\
\text { the market, cinema, meeting } \\
\text { friends, returning to place of } \\
\text { origin) }\end{array}$ & $23.30 \%$ & $53.70 \%$ \\
\hline $\begin{array}{l}\text { \% of HH who report harassment } \\
\text { problems }\end{array}$ & $6.80 \%$ & $47.30 \%$ \\
\hline $\begin{array}{l}\text { \% of HH who feel cheated } \\
\text { because wages are not disclosed } \\
\text { because production records are } \\
\text { not disclosed } \\
\text { other reasons }\end{array}$ & $8.5 \%$ & $82 \%$ \\
\hline$\%$ of HH who know the wage & $83.50 \%$ & $71.3 \%$ \\
\hline $\begin{array}{l}\text { \% of HH who bargain with } \\
\text { maistries or employers }\end{array}$ & $92.50 \%$ & $29.8 \%$ \\
\multicolumn{1}{c|}{$\begin{array}{l}\text { for better wages } \\
\text { for other things }\end{array}$} & $42.50 \%$ & $6.7 \%$ \\
\hline
\end{tabular}

Source: fieldwork 
Various factors contribute to this. Dry zone households remain at the brick kilns for longer periods of time and thus produce more. Their growing season at the village is shorter, allowing them to depart by the end of December, while workers from the wetlands leave only in late January after the last harvest. As previously discussed, dry zone workers are more experienced. Insofar as employment conditions are extremely opaque and many issues are negotiated personally, this gives them a clear advantage. Their experience allows them to get better positions within the production hierarchy as loaders, bullock card drivers or maistries. As Table 6 shows, workers from drylands are more able to occupy such positions.

Table 6. Occupation within the brick kilns

\begin{tabular}{|l|l|l|}
\hline $\begin{array}{l}\text { Worker Position } \\
\text { within the industry }\end{array}$ & dry & irrigated \\
\hline Moulder & $75.73 \%$ & $96.84 \%$ \\
\hline Loader/unloader & $11.65 \%$ & $2.11 \%$ \\
\hline Bullock card driver & $8.74 \%$ & $0.00 \%$ \\
\hline Watchman & $0.00 \%$ & $1.05 \%$ \\
\hline Maistry & $3.88 \%$ & $0.00 \%$ \\
\hline & $100.00 \%$ & $100.00 \%$ \\
\hline
\end{tabular}

Source: fieldwork

To compare wages just for moulders, and taking into account a shorter working time, there is still a wage difference of 18 percent. Two main factors explain this difference: the workers' industry know-how, and their bargaining power with the maistries.

Labourers from dry villages have explored and worked in many - sometimes dozens - of places, and know their strengths and weaknesses. The biggest units are concentrated in the Red Hills area in suburban Chennai. They have not only large production capacities but also storage facilities. This allows them to enjoy much better market prices than chambers obliged to sell bricks immediately. They are located in towns, which facilitates travel and access to health care and sometimes education (through partnerships with NGOs). Many small units are then located further south in different parts of Kancheepuram district, well known for its sand quality. Production is often much lower and fluctuating, owing to competition and access to sand. While the Red Hills chambers are able to negotiate group licenses, this is not the case for the southern kilns. These units are far more notorious for poor working and living conditions, probably because of their geographical 
isolation and higher productivity pressures (although this interrelationship needs to be investigated further). When they have the choice, workers try to avoid Kancheepuram chambers.

Relationships with maistries are also clearly important. They recruit, distribute the advances, partly supervise the work, and settle the accounts at the end of the season. This comes at a cost: the maistries' remuneration comes as a percentage of workers' wages. The more the workers produce the better the maistries are paid, and the higher the piece rate, the more they can get. This is negotiated at the end of the season with the brick kiln supervisor, when all the accounts are settled. Workers are excluded from the negotiations. Then they are informed about their own accounts, but never the details of the calculations. This gives the maistries some freedom, but they also have to retain their workers' loyalty, and for at least this part, the workers' bargaining power is crucial. Here too, workers from the dry villages have an obvious advantage, as they know the maistries. In the villages we studied, all of the maistries without exception came from dry villages. The industry relies on the labourers from drylands to keep themselves in business, a point on which the maistries and employers are very clear: without the workers from dry areas, they cannot work. Recruiting and monitoring labourers from the wet areas is much more complicated, as they are so dispersed. Murali, who has been a maistry for around ten years, explained that in wet areas he needed to visit at least 10 villages to mobilize a batch of 20 labourers, while in dry areas one village is enough. The maistries have to ensure that workers will turn up on the departure day and that they won't disappear before the end of the season.

When labourers are dispersed spatially it is therefore much more challenging to control them. Other maistries complain about workers' unreliability. Perumal, for instance, explains that 'labourers from wet villages are not reliable. They only come when they need us. How can we manage the production? Good workers we can help. We give big advances, bonus. Bad workers, we can't. They should understand our constraints'.

Workers from wet zones have therefore limited choices. Even if they wished to specialize in brick kiln work, they could not. If they are not 'reliable, very simply this is also because they cannot reliably expect work to be available. Brick kiln production is not only seasonal but also highly fluctuating, due to climactic factors - unexpected rain stops production - access to raw material and variations in the construction market. Some maistries clearly state that they only look for workers from wet areas at times of a production peak or when they are unable to offer the large advances demanded by workers from dry areas, as workers from wet areas are less demanding. For instance Rajendran, a young maistry, explained to us that last year ten workers escaped and he lost around 100000 rupees. This year he is bringing new labourers, but with lower advances. Though there are many labourers available in the area, he went to wet villages to enrol labourers. 'Here they are asking for 20000 rupees, he says, whereas there they only ask for 8000 rupees'.

One might think that workers from the drylands profit from their relatively better situation to struggle as a group for better working conditions, but their slightly better conditions still fall far below decent labour standards, and there are no forms of collective action. Murali, a maistry, explained that the situation comes down to the following: 
'There is one [labour association] for the chamber owner. [For workers] there is no use for that, as the owners decide to pay high if the worker works fast. And less if they don't work. And moreover the workers are varied and so we cannot form a group'.

To the question of labour legislation, he replies: 'we don't follow any law. We just pay the advance from the employer, collect the workers and take them to the chamber, get the work done and then return to the place'.

We met some workers who had subscribed to social insurance schemes, but they had all dropped them. Some were unable to renew their subscription, while others had failed to enforce their rights and were totally discouraged. The maistries represent the workers to the brick kilns supervisors and employers. When they have some room for manoeuvre, they use it mainly to negotiate their own commission. Meanwhile some of the workers, particularly the more experienced ones, try to discuss wages. However our data collected from the maistries reveal that while between 2000 and 2009 wages significantly increased, advances increased much faster. One can therefore suspect that a growing number of workers returning indebted at the end of the season.

Table 7. Advances and wages from 2000 to 2009 (index price 2004)

\begin{tabular}{|c|c|c|c|c|c|c|}
\hline & 2000 & 2004 & $\begin{array}{l}\text { Diff } \\
\text { 2004-2009 }\end{array}$ & 2009 & \begin{tabular}{|l|} 
Diff \\
$2009-$ \\
2004 \\
\end{tabular} & \begin{tabular}{|l} 
Dif \\
$2009-$ \\
2009 \\
\end{tabular} \\
\hline Advance & 8743 & 10610 & $+21.35 \%$ & 16214 & $+52.82 \%$ & $+74.17 \%$ \\
\hline Total wage & 16517 & 18096 & $+9.56 \%$ & 23217 & $+28.29 \%$ & $+37.85 \%$ \\
\hline
\end{tabular}

Source: fieldwork

During our last field visit in 2009, we met employers who had built partnerships with consumer goods companies providing motorcycles, fridges, grinders, etc. to the workers. Here too repayments are deducted from the wages. Our observations show that purchases on credit are 20 percent more expensive than cash. The employers argue that this is a 'boon' for the workers, claiming that they offer 'favours' to 'good' workers, allowing them to save money. Murali, a maistry, gives us a different picture:

'There is not just the health problem, they cannot send their children to school, they cannot have animals in the house. If you visit the chamber we cannot find out who is who, they look not as humans. It is because they have to work more as they had taken an advance greater 
than what they can repay. Sometimes the couples run off without repaying the money and we have to get the help of the police to get back the money'.

It is likely that the employers' strategy is above all a means to cope with the strong growth of the construction sector over the recent years. The brick industry has been backed by a vast housing scheme from the Tamil Nadu government and was unaffected by the global economic crisis, unlike the rest of the informal economy (Venkatesh 2009). The price of bricks has more than doubled over the past few years. To overcome labour shortages, employers increased wages but also and above all advances: as indicated in Table 7 , real wages increased by 38 percent and advances increased much faster $(+74$ percent on average).

\section{Conclusion}

This microstudy sheds light on the diverse nature of brick kiln circulation experiences, how it is shaped by village life and the needs of capital, and how this leads to increasing differentiation of rural labour. Brick moulders come mainly from villages from dry areas. With agricultural decline and the departure of the big high-caste landowners, over time these villages have specialized in a specific, well-established migration circuit. Although working conditions violate the most basic labour standards, the brick kiln sector is seen by workers as a tool for integration into 'modern' life. It is also considered as a tool for emancipation from local hierarchies, although these disappeared a long time ago and no longer offer any prospect of employment or protection. In wet areas by contrast, where both agriculture and social stratification have evolved but still continue to play a more important role, brick kiln circular migration is both sporadic and unstructured. For this reason, it offers even worse working and living conditions, which only the most vulnerable accept - and some even cannot access kiln employment as they lack the right contacts. This leaves the village moral economy as a better option.

One might ask why seasonal migrants persist in the brick industry, when other occupations and destinations in different parts of Tamil Nadu or South India offer far better working conditions. This is the case for instance in construction (see Pattenden in this volume) or in knitwear (Heyer in this volume). The advance is a first factor. The workers do not experience advance payment as bondage, but as a strengthening of their bargaining position (Breman 2007: 88; see also Guérin and Venkatasubramanian 2009). The great merit of the wage advance - and here lies the whole perversity of the system - is to act as a job guarantee. Until the debt is repaid, borrowers are forced to work, but they are also confident in having a job! The workers meanwhile need these lump sums to cope with the slack season, to deal with health problems and address their growing consumer needs. The social regulation of migration channels is the second factor (Harriss-White 2003, 2010; Harriss-White and Gooptu 2001). Although labour relations are outside all forms of legislation, they are highly structured, so that not just anyone can leave to take up work anywhere (see also Picherit, this volume). Employers need a productive, disciplined, loyal and cheap workforce. Debt is a means to attract and retain workers until the end of the season, and to compress wages. Personal links with both labourers, their neighbourhoods and the power structures of the source village, and labour intermediaries are a way to control workers and ensure they do not 'escape'. Workers are thus 
selected cautiously, and in turn, whatever the destination, workers rarely take the risk of leaving alone. Intermediaries are needed to find a place to live, an employer who is willing to recruit, and to withstand harsh competition from other workers. In the absence of formal regulation and labour contracts, personal relationships are the best way to limit the risks for both employers and workers.

The contrast between these two cases might seem extreme. The opposition between dry and wetlands is both arbitrary and relative. We are not making a case for ecological determinism - the importance of other factors for circulation patterns has also been pointed out - but we want to emphasize the segmentation of one specific labour market and how this plays out both in terms of distinct village economies and the different needs and constraints of the brick industry. Brick labour markets consist of non-competing labourers whose options are not only severely constrained, but also highly diverse. Labourers are so isolated that they face different wage levels and working conditions, which is the very definition of segmentation in economic theory. This study has also highlighted the lived experience of circulation, and how it intersects with the significantly divergent testimonies of the labourers: brick moulding is either seen as a way to cope with agricultural distress, or as a means to integrate into society, not just as labourers but as consumers.

As far as policy is concerned, one might wonder when and how Indian public authorities will have the political will to implement a decent labour agenda. Labour laws exist but have limited coverage and are poorly implemented (NCEUS 2009: 180). Far beyond bonded labour, brick kiln employers violate many other basic labour standards that are officially forbidden by the Indian legislation. This is the case in terms of child labour, working hours, provident funds, migrant labour and contract labour, to name but a few. ${ }^{9}$ Minimum wages exist and are almost met in the local kiln industry, but the amounts, which are fixed as a piece wage, are absolutely incompatible with decent daily wages. The absence of political will, administrative indifference and alliances between public authorities and employers all contribute to this (Breman 2007, Harriss-White 2003, Lerche 2007), and brick kilns of Tamil Nadu are no exception (Guérin and Venkatasubramanian 2009).

While significant progress has been made in recent years as regards social security in relation to informal labour programmes, here too implementation is a source of concern (Harriss-White 2011, Hensman 2011). In Tamil Nadu, which is considered as one of the pioneer states in adopting specific measures for the unorganised sector, a Construction Workers Welfare Board has existed since 1994. Workers are officially eligible to various sorts of benefits, ranging from compensation in the case of accidents to educational assistance (Government of Tamil Nadu 2010). At the time of our last field visit in June 2009, it seems that none of these had reached the brick kiln workers, at least in the source village we studied. Regulation meanwhile is still off the agenda (see Lerche, this volume). Here we see how the anti-poverty programs, of which Tamil Nadu is a champion, obscure the structural reforms that are needed for a social democratic transformation of the society (Harriss 2010).

It would however be naïve to hope that employers themselves will stop these inhumane forms of labour management. Debt bondage in the brick industry is supported by the decline in the availability of agricultural labour and lack of social protection but also by the growing consumption needs of labourers. Paradoxically, increasing aspirations for equality and integration are helping to reproduce the conditions for capitalist exploitation and extraction of surplus value. Without massive political intervention, there is little hope for the future resolution of the problems of debt bondage. 


\section{NOTES}

1. See for instance da Corta and Venkateshwarlu (1999), Harriss (1992), Jodhka (1994), Lerche (1999), Marius-Gnanou (2008).

2. Food insecurity is defined subjectively; labourers themselves were asked to reply to the question 'do you suffer from food insecurity'?

3. For a case study in Tamil Nadu, see Harriss et al. (2010). For a review, see Platteau (1995).

4. For a historical analysis, see Ludden (2005). For contemporary analysis, see for instance Bouton (1985), Chambers and Harriss (1977), Djurfeldt et al. (2008), Epstein (1973), Epstein et al. (2002), Landy (1994), Racine (1994), Ramachandran and Rawal (2010), Venkatesh et al. (1986).

5. See for instance Breman (1996), Harriss (1992), Harriss-White (2003), Lerche (2010), Srivastava (2005), Racine (1994).

6. These are very small and temporary production units.

7. Drawing on brick kiln migrants in Jharkhand, Alpa Shah argues that far beyond economic motivations, migration to brick kilns is very often seen and experienced in terms of liberation from an oppressive local environment of growing moral puritanism, whether sexual life, food or domestic disputes. This is not the case here, as workers already enjoy relative freedom at home. What we observe here is a feeling of emancipation and integration drawing on outside work and consumption.

8. In 2004-5, the Planning Commission of India fixed the poverty line at around 20000 INR per household for rural Tamil Nadu. This amount is clearly under-evaluated (Subramanian 2011).

9. Prohibition of Child Labour in Hazardous Industries Act (1970); Employment Provident Fund and Miscellaneous Provisions Act (1971); Factory Act (1948), which regulates working hours and provides compensation for overtime; Inter-State Migrant Workmen Act (1979) which provides for specific measures (housing, medical coverage, etc.) when more than 50 percent of a company's work force are migrants; Contract Labour (Regulation and Abolition) Act, 1970, which aims at limiting the use of contract labour and providing social benefits to contract labourer.

\section{REFERENCES}

Béteille, A. (1965) Caste, Class, and Power: Changing Patterns of Stratification in a Tanjore Village. Berkeley and Los Angeles: University of California Press. 
Bouton, M.M. (1985) Agrarian Radicalism in South India. Princeton: Princeton University Press.

Breman, J. (1986) Of Peasants, Migrants and Paupers: Rural Labour Circulation and Capitalist Production in West India. New Delhi: Oxford University Press.

Breman, J. (1996) Footloose Labour: Working in the Indian Informal Economy. Cambridge: Cambridge University Press.

Breman, J. (2007) Labour Bondage in West India. From Past to Present. Oxford: Oxford University Press.

Breman, J. (2011) Outcast Labour in Asia. Circulation and Informalisation of the Workforce at the Bottom of the Economy. New Delhi: Oxford University Press.

Breman, J., Guérin, I. and Prakash, A. (ed). (2009) India's Unfree Workforce. Old and New Practices of Labour Bondage. New Delhi: Oxford University Press.

Chambers, R. and Harriss, J. (1977) 'Comparing Twelve South Indian Villages: In Search of Practical Theory', in B.H. Farmer (ed) Green Revolution? (pp. 301-322). London: Macmillan.

Chatterjee, P. (2011) 'Democracy and Economic Transformation in India', in S. Ruparelia, S. Reddy, J. Harriss and S. Corbridge (ed) Understanding India's New Political Economy (pp. 1734). London and New York: Routledge.

da Corta, L. and Venkateswarlu, D. (1999) 'Unfree Relations and the Feminisation of Agriculture Labour in Andhra Pradesh, 1970-95', in T.J. Byres, K. Kapadia and J. Lerche (eds) Rural Labour Relations in India (pp. 71-139). London: Frank Cass.

Djurfeldt, G., Athreya, V., Jayakumar, N., Lindberg, S., Rajagopal, A. and Vidyasagar, R. (2008) 'Agrarian Change and Social Mobility in Tamil Nadu', Economic and Political Weekly 43(45): $50-62$.

Epstein, T.S. (1973) South India - Yesterday, Today and Tomorrow. Mysore Villages Revisited. London: MacMillan.

Epstein, T.S., Suryanarayana, A.P. and Thimmegowda, T. (2002) Village Voices. Forty Years of Rural Transformation in South India. New Delhi: Thousand Oaks/London: Sage.

Gidwani, V. and Sivaramakrishnan, K. (2003) 'Circular Migration and Rural Cosmopolitanism in India', Contributions to Indian Sociology 37(1/2):339-367. 
Government of Tamil Nadu (2010) Policy Note on Labour, Factories, Employment and TrainingDemand $n^{\circ} 32$. Chennai: Labour and Employment Department.

Guérin, I. and Venkatasubramanian, G. (2009) 'Corridors of Migration and Chains of Dependence: Brick Kiln Moulders in Tamil Nadu', in J. Breman, I. Guérin and A. Prakash (eds) India's Unfree Workforce: Old and New Practices of Labour Bondage (pp. 170-197). New Delhi: Oxford University Press.

De Haan, A. (2011) 'Inclusive Growth and Labour Migration in India', Working Paper no. 513, The Hague: International Institute of Social Studies. Available at: http://repub.eur.nl/res/pub/22201/wp513.pdf. (accessed 10 March 2011).

Harriss, J. (1992) 'Does the "Depressor" Still Work? Agrarian Structure and Development in India: A Review of Evidences and Arguments', The Journal of Peasant Studies 19(2): 189-227.

Harriss, J. (2010) 'Globalization(s) and Labour in China and India: Introductory Reflections', Global Labour Journal 1(1): 2-11.

Harriss, J., Jeyaranjan, J. and Nagaraj, K. (2010) 'Land, Labour and Caste Politics in Rural Tamil Nadu in the Twentieth Century, Iruvelpattu 1916-2008', Economic and Political Weekly 45(31): 47-61.

Harriss-White, B. (2003) India Working. Essays on Society and Economy. Cambridge: Cambridge University Press.

Harriss-White, B. (2010) 'Globalisation the Financial Crisis and Petty Commodity Production in India’s Socially Regulated Informal Economy’, Global Labour Journal 1(1): 152-177.

Harriss-White, B. and Gooptu, N. (2001) 'Mapping India’s World of Unorganised Labour', Socialist Register (Working Classes: Global Realities) 37: 89-118.

Hensman, R. (2010) 'Labour and Globalisation: Union Responses in India', Global Labour Journal 1(1): 112-131.

ILO (2009) The Cost of Coercion. Global Report Under the Follow-up to the ILO Declaration of Fundamental Principles and Rights at Work Geneva: ILO.

Jodhka, S.S. (1994) 'Agrarian Changes and Attached Labour: Emerging Patterns in Haryana Agriculture', Economic and Political Weekly 29(39): A102-A106.

Landy, F. (1994) Paysans de l'Inde du Sud. Paris: Editions Karthala-IFP. 
Lerche J. (2010) 'From "Rural Labour" to "Classes of Labour": Class Fragmentation, Caste and Caste Struggle at the Bottom of the Indian Labour Hierarchy', in B. Harriss-White and J. Heyer (eds) The Political Economy of Development: Africa and South Asia Compared (pp. 64-85). London: Routledge.

Lerche, J., (2007) 'A Global Alliance Against Forced Labour? Unfree Labour, Neo-liberal Globalization and the International Labour Organization', Journal of Agrarian Studies 7(4): 425-452.

Lerche, J. (1999) 'Politics of the Poor: Agricultural Labourers and Political Transformations in Uttar Pradesh', in T.J. Byres, K. Kapadia and J. Lerche (eds) Rural Labour Relations in India (pp.182-242). London: Frank Cass.

Ludden, D. (2005) Early Capitalism and Local History in South India. New Delhi: Oxford University Press.

Marius-Gnanou K. (2008) 'Debt Bondage, Seasonal Migration and Alternatives Issues: Lessons From Tamil Nadu, India', Autrepart 2(46): 127-142.

Michiels, S. (2009) 'Etude des populations de travailleurs migrants : l'exemple des briquèteries en Inde du Sud', MPhil Thesis Economie Appliquée. Bordeaux: Université de Montesquieu Bordeaux IV.

NCEUS (National Commission for Enterprises in the Unorganised Sector) (2007) Report on Conditions of Work and Promotion of Livelihood in the Unorganised Sector. NewDelhi: NCEUS, Government of India.

NCEUS (National Commission for Enterprises in the Unorganised Sector) (2009) The Challenges of Employment in India, vol. I, main report. New Delhi: NCEUS, Government of India.

Racine, J.-L. (ed) (1994) Les Attaches de l'homme. Enracinement paysan et logique migratoire en Inde $d u$ Sud. Paris: Edition de la Maison des Sciences de l'Homme.

Osella, F. and Osella, C. (2000) Social Mobility in Kerala. Modernity and Identity in Conflict. London/Sterling: Pluto Press.

Pattenden, J. (2011) 'Gatekeeping as Accumulation and Domination: Decentralisation and Class Relations in Rural South India', Journal of Agrarian Change 11(2):164-194.

Picherit, D. (2009) “"Workers, Trust Us!": Labour Middlemen and the Rise of the Lower Castes in Andhra Pradesh', in J. Breman, I. Guérin and A. Prakash (eds) India's Unfree Workforce: Old and New Practices of Labour Bondage (pp. 259-283). New Delhi: Oxford University Press. 
Picherit, D. (2009) 'Entre villages et chantiers: circulation des travailleurs, clientélisme et politisation des basses castes en Andhra Pradesh, Inde', PhD in Anthroplogy, University Paris Ouest Nanterre la Défense.

Platteau, J.-Ph. (1995) 'A Framework for the Analysis of Evolving Patron-client Ties in Agrarian Economies', World Development 23(5): 767-786.

Prakash, A. (2009) 'Towards Understanding the Nature of Labour Markets in Brick Kilns' in J. Breman, I. Guérin and A. Prakash (eds) India's Unfree Workforce: Old and New Practices of Labour Bondage (pp. 198-232). New Delhi : Oxford University Press.

Ramachandran V.K., Rawal, V. and Swaminathan, M. (2010) Socio-Economic Survey of Three Villages in Andhra Pradesh: A Study of Agrarian Relations. New Delhi: Tulika Books.

Ramachandran, V.K., and Rawal, V. (2011) 'The Impact of Liberalisation and Globalisation on India's Agrarian Economy', Global Labour Journal 1(1): 56-91.

Rogaly, B. and Choppard, D. (2003) “They Used To Go to Eat, Now They Go to Earn”: The Changing Meanings of Seasonal Migration from Puruliya District in West Bengal, India', Journal of Agrarian Change 3(3): 395-433.

Shah, A. (2006) 'The Labour of love: Seasonal Migration from Jharkhand to the Brick kilns of Other States in India', Contributions to Indian Sociology 40: 91-118.

Srivastava, R.S. (2005) 'Bonded Labour in India: Its Incidence and Pattern' Working Paper Declaration/WP/43.

Srivastava, R. (2009) 'Conceptualising Continuity and Change in Emerging Forms of Labour Bondage', in J. Breman, I. Guérin and A. Prakash (ed) India's Unfree Workforce. Old and New Practices of Labour Bondage (pp.129-146). New Delhi: Oxford University Press.

Subramanian S. (2011) The Poverty Line: Getting it Wrong Again', Economic and Political Weekly 46(48): 37-42.

Vakulabharanam, V. and Motiram, S. (2011) 'Political Economy of Agrarian Distress in India Since the 1990s', in S. Ruparelia, S. Reddy, J. Harriss, S. Corbridge (eds) Understanding India's New Political Economy (pp. 101-126). London and New York: Routledge.

Venkatesh, A.B., Boklin, G., Djurfeldt, G. and Lindberg, S. (1986) 'Production Relations and Agrarian Change: Some Findings from a Case Study in Tamil Nadu', Social Scientist 14(5): 314. 
Venkatesh, A.B. (2009) 'The Economic Crisis and Rural Livelihood', Swaminathan Foundation, unpublished Available at: http://www.agrarianstudies.org/UserFiles/File/Athreya,\%20_The\%20Economic\%20Crisis\%20 and\%20Rural\%20Livelihoods.pdf (accessed 15 March 2011).

Wood, G. (2003) 'Staying Secure, Staying Poor: The "Faustian Bargain”', World Development 31(3): 455-471.

\section{BIOGRAPHICAL NOTES}

ISABELLE GUÉRIN is Research Fellow at University Paris I Sorbonne/Institute of Research for Development (Development and Societies Research Unit) and is affiliated to the French Institute of Pondicherry. She is a socioeconomist specialising in credit and labour markets. Her specific areas of interest include bonded labour, informal finance and microfinance, with a specific focus on WestAfrica and South India.

SUBRAMANIAN PONNARASU is presently a PhD student in anthropology at Pondicherry University. He is also Project Co-investigator for 'Constituting a Digital Archive of Tamil Agrarian History' (EAP 458) at the French Institute of Pondicherry.

GOVINDAN VENKATASUBRAMANIAN is Research Fellow at the French Institute of Pondicherry. He is a sociologist, specialising in rural development, labour, finance and rural-urban linkages in Tamil Nadu.

SÉBASTIEN MICHIELS is presently a PhD student in development economics at Bordeaux IV University (GREThA), and affiliated to the French Institute of Pondicherry. 